\title{
Chemokine Receptors CCR1 and CCR2 on Peripheral Blood Mononuclear Cells of Newly Diagnosed Patients with the CD38-Positive Chronic Lymphocytic Leukemia
}

\author{
Irina Kholodnyuk ${ }^{1, *,+} \mathbb{1}$, Alla Rivkina ${ }^{2,3,+}$, Laura Hippe ${ }^{1} \mathbb{D}$, Simons Svirskis ${ }^{1}$, \\ Svetlana Kozireva ${ }^{1}$, Ildze Ventina ${ }^{1}$, Irina Spaka ${ }^{1}$, Marina Soloveichika ${ }^{3}$, Jelena Pavlova ${ }^{1}$, \\ Modra Murovska ${ }^{1}$ (D) and Sandra Lejniece ${ }^{2,3}$ \\ 1 Institute of Microbiology and Virology, Riga Stradins University, LV-1067 Riga, Latvia; \\ Laura.Hippe@rsu.lv (L.H.); Simons.Svirskis@rsu.lv (S.S.); Svetlana.Kozireva@rsu.lv (S.K.); \\ ildze.ventina@gmail.com (I.V.); irina.spaka@inbox.lv (I.S.); Jelena.Pavlova@rsu.lv (J.P.); \\ Modra.Murovska@rsu.lv (M.M.) \\ 2 Department of Internal Diseases, Riga Stradins University, LV-1038 Riga, Latvia; Alla.Rivkina@rsu.lv (A.R.); \\ Sandra.Lejniece@rsu.lv (S.L.) \\ 3 Riga East University Hospital, Clinic of Chemotherapy and Hematology, LV-1038 Riga, Latvia; \\ marina.soloveicika@aslimnica.lv \\ * Correspondence: Irina.Holodnuka@rsu.lv; Tel.: +371-67-060-840 \\ + Authors contributed equally.
}

Received: 16 June 2020; Accepted: 17 July 2020; Published: 21 July 2020

\begin{abstract}
Chemokines and their receptors direct migration and infiltration of immune cells. CCR1 and CCR2 maintain sequence similarity and respond to a number of the same chemokines secreted in lymphoid organs. Expression of CD38 on leukemic cells has been associated with poor clinical outcomes in patients with chronic lymphocytic leukemia (CLL) and is considered as the negative predictor of progression. In our study of newly diagnosed CLL patients, which included 39 CD38-positive and 22 CD38-negative patients, CCR1 and/or CCR2 were always detected, using flow cytometry, on the peripheral blood (PB) $\mathrm{CD} 19^{+} \mathrm{CD}^{+}$lymphocytes in patients with $>30 \%$ of the $\mathrm{CD} 38^{+} \mathrm{CD} 19^{+} \mathrm{CD}^{+}$lymphocytes $(n=16)$. Spearman's rank correlation analysis determined correlations between the frequency of the CCR1- and CCR2-expressing PB CD19 ${ }^{+} \mathrm{CD}^{+}$ lymphocytes and the frequency of the CD38-positive CD19+CD5 lymphocytes $\left(r_{s}=0.50\right.$ and $r_{s}=0.38$, respectively). No significant correlations were observed between ZAP70 mRNA expression levels in $\mathrm{PB}$ mononuclear cells and the frequency of the circulating $\mathrm{CCR} 1^{+}$or $\mathrm{CCR} 2^{+} \mathrm{CD} 19^{+} \mathrm{CD} 5^{+}$lymphocytes. Further association studies are needed to verify prognostic relevance of the CCR1/CCR2 expression on leukemic cells in CLL patients at diagnosis. We suggest that CCR1/CCR2 signaling pathways could represent attractive targets for development of CLL anti-progression therapeutics.
\end{abstract}

Keywords: CCR1; CCR2; CLL; CD38; CD19+CD5 lymphocytes

\section{Introduction}

Chemokines and their receptors represent an important network of the immune system. Chemokines transmit signals via corresponding cell-surface $G$ protein-coupled receptors. The chemokine receptors CCR1 and CCR2, comprising significant protein sequence homology, share responses to a number of inflammatory chemokines (reviewed in $[1,2]$ ) that are induced upon inflammation and under many pathophysiological conditions. Disease association studies, based on animal models and ex vivo 
human tissues and cells, implicated T-cells and monocyte/macrophage expression of CCR1 and/or CCR2 in the development of inflammatory disorders, autoimmune diseases, and cancer progression (reviewed in [3]).

CCR2 expression on human B lymphocytes in peripheral blood (PB) and tonsils was first reported in 1997 by Frade et al. [4]. Both CCR1 and CCR2 were detected on B cells isolated from tonsils of healthy donors, on memory $\left(\mathrm{CD} 38^{-} \mathrm{IgD}^{-}\right)$and naïve $\left(\mathrm{IgD}^{+}\right)$non-germinal center $\mathrm{B}$ cells, but not on germinal center (GC) B cells (CD38 $\left.{ }^{+} \mathrm{IgD}^{-}\right)$[5]. However, only a small proportion of the PB-circulating normal B lymphocytes expressed CCR2 (2.9-7.9\% of $\mathrm{Ig}^{+}$cells), with no difference observed in expression between $\mathrm{IgA}^{+}$and $\mathrm{IgG}^{+}$cells [6]. The $\mathrm{CD} 19^{+} / \mathrm{HLA}^{-\mathrm{DR}^{+}} \mathrm{B}$ cells in the PB of healthy individuals were also defined by multiparameter flow cytometry analysis as CCR2-negative [7]. Nevertheless, on malignant $\mathrm{B}$ cells obtained from 38 patients with non-Hodgkin lymphomas, the cell-surface expression of CCR1 and CCR2 varied in different types of B-cell lymphomas and was detected in $69 \%$ and $46 \%$, respectively, of patients with chronic lymphocytic leukemia (CLL), but only in $0 \%$ and $17 \%$ cases, respectively, of small lymphocytic leukemia [8]. An immunohistochemical study, using hierarchical cluster analysis, demonstrated that CCR1-staining correlated with an activated B-cell type of diffuse large B-cell lymphoma [9]. Previously, we also revealed that both CCR1 and CCR2 are up-regulated in $\mathrm{B}$ cells that were isolated from the $\mathrm{PB}$ of healthy donors and activated by the in vitro treatment with mitogens (IL-4 and anti-CD40) or upon infection with Epstein-Barr Virus (EBV). Notably, the established lymphoblastoid B-cell lines (LCL) were CD10-negative and expressed CCR1, CCR2, and CD38 at moderate level [10].

Chronic lymphocytic leukemia (CLL) is the most common form of leukemia in adults. It accounts for about $1 / 4$ of the new cases of leukemia. CLL disease is characterized by highly variable clinical courses (reviewed in [11,12]. About 30\% of CLL patients survive to more than 15 years [13], including patients who do not require therapy for many years (up to 20 years), and may never need any treatment; while patients with an aggressive form survive no more than 3 years after the diagnosis and require therapy immediately after the diagnosis $[11,14,15]$. Patients with slowly progressing CLL are not recommended for therapy unless they have evidence of disease progression [12,15]. Chemotherapy-based regimens may cause complications: an increased risk of infections and myelosuppression, and, in a subset of CLL patients, post-therapy myelodysplasia and secondary cancers, such as acute myeloid leukemia $(\sim 5 \%)$, Richter syndrome $(2-7 \%)$-the transformation of CLL to an aggressive lymphoma (DLBCL, Hodgkin lymphoma) (reviewed in [11]). Two clinical staging systems, the Rai and the Binet classification, are widely used in clinical practice to define patients with the early- (low-risk), intermediate-, and late-stage (high-risk) CLL [16,17]. The late-stage, or high-risk, disease is characterized by the presence of pronounced anemia or thrombocytopenia. In daily clinical practice, the indication for the patient treatment depends on the clinical stage and disease-related symptoms [12]. However, traditional staging systems cannot predict the clinical course in CLL patients with the early (low-risk) stage of disease $[18,19]$. Nowadays, two main types of CLL, namely slowly progressing and rapidly progressing, are distinguished by whether leukemic cells express a mutated or an unmutated immunoglobulin heavy chain variable region (IGHV) gene. CLL patients with the unmutated IGHV gene in leukemic cells generally have a more aggressive disease than patients with the mutated IGHV gene $[20,21]$. The IGHV mutational status is a parameter that is currently determining the choice of therapy [11]. Since CD38 (cyclic ADP-ribose hydrolase 1) expression in CLL cells has been associated with unmutated IGHV and shorter overall survival in patients with CLL, CD38 was proposed as a surrogate marker of the IGHV somatic mutation status in CLL [20,22,23]. An association between the CD38 expression on PB CLL cells and the more aggressive CLL disease, when patients had the reduced time-to-first treatment, progression-free survival, and overall survival, was confirmed by numerous reports. CD38 is accepted as an indicator of activated CLL cells; CD38-expressing leukemic cells are characterized by enhanced response to B-cell receptor (BCR) signaling and increased cell migration ability (reviewed [24]). Although CD38-expression levels vary throughout the course of the 
disease [25], CD38 showed better concordance with the IGHV mutation status than did tyrosine-protein kinase ZAP-70 (zeta chain of T cell receptor associated protein kinase 70) [26,27].

Three studies reported in 2015 that the high EBV DNA load in peripheral blood mononuclear cells (PBMC) (>1000 copies/ $\mu$ g DNA) at CLL diagnosis was significantly associated with therapy response [28], shorter time to disease progression and time to first treatment [29], and a 3.14-fold increased hazard ratio of death and poor overall survival [30].

We focused our study on newly diagnosed patients with the CD38-positive CLL. In this study of 61 newly diagnosed CLL patients, which included 39 patients presenting with CD38 on leukemic cells, we assessed the cell-surface expression of the chemokine receptors CCR1 and CCR2 in the PBMC populations that included $\mathrm{CD} 19^{+} \mathrm{CD}^{+}, \mathrm{CD} 19^{+} \mathrm{CD}^{-}$, and $\mathrm{CD} 19^{\mathrm{TM}}$ (designated as T-NK) lymphocytes and monocytes, using the multiparameter flow cytometry (mFC) method. We estimated correlations and evaluated the data in relation to expression of the negative prognostic marker CD38 on the $\mathrm{CD} 19^{+} \mathrm{CD}^{+}$lymphocytes. The ZAP70 mRNA expression levels in PBMCs and the EBV copy numbers were determined as well.

\section{Experimental Section}

\subsection{Patients}

Sixty-one patients, newly diagnosed with CLL in the Clinic of Chemotherapy and Hematology (CCH) at Riga East University Hospital (REUH, Latvia) during 2014-2019, were included in the study. PB samples were collected from patients who had an increase of B lymphocytes $\left(>5 \times 10^{9} / \mathrm{L}\right)$ in the blood. For the primary diagnosis, PB samples were analyzed on the same day by flow cytometry (FC) for the co-expression of the CD markers CD19, CD20, CD22, CD5, CD23, and CD38. The primary CLL diagnosis was made when cells co-expressed the B-cell marker(s) CD19/CD20 (with or without CD22), CD23, and CD5. The Rai classification was applied to characterize the clinical stages [16]. For this report, we re-considered the clinical stages of the involved CLL patients according to the recommendations of the consensus guidelines of the International Workshop on Chronic Lymphocytic Leukemia (IWCLL), which were updated in 2018 [12]. According to this updated classification, patients with blood B-cell lymphocytosis $\left(>5 \times 10^{9} / \mathrm{L}\right)$, the immunophenotype CD19 $/ \mathrm{CD} 20^{+} \mathrm{CD} 23^{+} \mathrm{CD}^{+}$of $\mathrm{PB}$ cells, and disease-related anemia (blood hemoglobin concentration $<11 \mathrm{~g} / \mathrm{dL}$ ) or thrombocytopenia (platelet blood count $<100 \times 10^{9} / \mathrm{L}$ ) were defined as patients with the high-risk disease (Rai stages III and IV, respectively). Intermediate-risk disease included patients with blood lymphocytosis, the typical immunophenotype, and lymphadenopathy or splenomegaly and/or hepatomegaly (Rai stage I and II, respectively). Patients with the typical immunophenotype and only lymphocytosis were defined as having the low-risk disease (Rai stage 0 ).

The REUH and Riga Stradins University (RSU, Latvia) Ethics Committees for Medical and Biomedical Research approved the study (ethics approval No 6-A/14 from 05 July 2014 and ethics approval No 6-3/4/19 from 25 April 2019, respectively). Informed consent was obtained from all patients involved in the study.

\subsection{Epstein-Barr Virus (EBV) DNA Load Quantification}

The EBV DNA copy number in the PBMC DNA samples of CLL patients was determined using an EBV Real-TM Quant Kit (Sacace Biotechnologies S.r.l., Como, Italy) with a sensitivity of not less than 200 copies/mL or 5 copies of $E B V$ DNA per $10^{5}$ cells. Real-time polymerase chain reaction (RT-PCR) was performed in duplicate according to the kit protocol in the CFX96 Touch Real-Time PCR Detection System (Bio-Rad Laboratories Inc., Richmond, CA, USA).

\subsection{Flow Cytometry Analyses}

After the primary CLL diagnosis in the clinical FC laboratory, the PB samples were stained with fluorochrome-conjugated anti-human mouse monoclonal antibodies (mAbs) according to the protocol, 
"Direct Immunofluorescence Staining of Whole Blood Using a Lyse/Wash Procedure" (BD Biosciences, San Jose, CA, USA). The cell-surface expression of CD45, CD19, CD5, CD14, CD38, CD191 (CCR1), CD192 (CCR2), and the membrane phospholipid phosphatidylserine (PS) in the PBMC populations was assessed by seven-color $\mathrm{mFC}$. The following fluorochrome-conjugated $\mathrm{mAbs}$, purchased from $\mathrm{BD}$ Biosciences, were used: CD45-Alexa Fluor 700 (clone HI30), CD19-FITC (clone HIB19), CD5-PE-Cy7 (clone L17F12) or CD5-BV510 (clone UCHT2), CD38-Horizon V450 (clone HB7), CD14-PE (clon M $\varphi$ P9), CD191-Alexa Fluor 647 (clone 53504), and CD192-Alexa Fluor 647 (clone 48607). Annexin V-PerCP-Cy5.5 and nonspecific mouse IgG1 and IgG2b, matching the respective fluorochrome and Ig-isotype of CD191 and CD192, were applied as the controls. For the analysis of the cell-surface expression of CCR1 (NP_001286) and CCR2 (NP_001116868/NP_001116513), we used mouse mAbs CD191-Alexa Fluor 647 (clone 53504) and CD192-Alexa Fluor 647 (clone 48607) in our previous work, where we confirmed the CCR1 and CCR2 expression on the cell-surface of B cells in Burkitt lymphoma and lymphoblastoid cell lines, defined using flow cytometry, by the fluorescent immunostaining, Western blot, RT-PCR, and cell migration analyses [10]. Apoptotic cells, which express the membrane PS, were stained with Annexin V-PerCP-Cy5.5 and were excluded from the analyses [31]. Autofluorescent cells were removed from each analysis by gating on viable cells in 2 ways, namely by using the PerCP-Cy5.5 fluorescence channel and by using the SSC/FSC dot-plots of the unstained cells. The CD45 $5^{+}$leukocytes were divided into granulocyte, monocyte $\left(\mathrm{CD} 14^{+}\right)$, and lymphocyte populations by gating on the SSC/FSC and SSC/PE dot-plots. The CD19-negative lymphocytes were counted and designated as T-NK lymphocytes. Seven-color mFC was performed; cells were scored and analyzed using the BD FACSAriaII or FACSAriaIIIu analyzers and Diva8.2 software (Becton, Dickinson and Company, Franklin Lakes, NJ, USA).

\subsection{Statistical Analyses}

Percentages of the CCR1- and/or CCR2-positive cells within the PBMC populations were summarized and presented as the medians with interquartile ranges (IQR: $25 \%$ percentile and $75 \%$ percentile). Data of clinical parameters, in the cases of unequal standard deviations, were presented as the medians and interquartile ranges. Data that were not normally distributed were analyzed using the Kruskal-Wallis (KW) test followed by post-hoc analysis, the two-stage step-up method of Benjamin, Krieger and Yekutieli (BKY). To compare proportions and differences between patient groups, the Chi-square test $\left(\mathrm{Chi}^{2}\right)$ was performed. The Spearman's rank correlation analysis was applied to determine the associations between the frequencies of the CCR1-, CCR2-, and CD38-positive cells within the $\mathrm{PB} \mathrm{CD} 19^{+} \mathrm{CD}^{+}$lymphocytes and the clinical parameters. Determined Spearman's rank correlation coefficients $\left(\mathrm{r}_{\mathrm{s}}\right)$ were reported as the correlation matrix images. The level of significant difference was selected using two-sided p-values less than $0.05(p<0.05)$. Statistical analyses were done using the GraphPad Prism version 8.0 (GraphPad Software, San Diego, CA, USA).

\subsection{Real-Time Polymerase Chain Reaction (RT-PCR) Analysis of ZAP70 Expression}

The ZAP70 (zeta chain of T cell receptor associated protein kinase 70; RefSeqGene NG_007727) gene expression was assessed in whole PBMC fractions at the mRNA level via real-time RT-PCR analysis. Real-time RT-PCR was performed using the first-strand cDNA (prepared from the total RNA that was reverse-transcribed with the random hexamer primer), gene-specific primers, the PerfeCTa SYBR Green FastMix (Quanta BioSciences Inc., Beverly, MA, USA), and the CFX96 Touch Real-Time PCR Detection System (Bio-Rad Laboratories Inc., Richmond, CA, USA). The ZAP70-specific primers and PCR protocol were described previously by Gladkikh et al. [32]. The values were normalized to the mRNA expression levels of GUSB (glucuronidase beta). This gene has been reported to be one of the three most suitable reference genes for PCR studies of CLL PB B cells [33]. A control cDNA sample, prepared from PBMC of the CLL patient with the low-moderate level of ZAP70 mRNA expression, was applied in each PCR run as an inter-run calibrator (IRC). The data were calculated relative to the IRC levels. 


\section{Results}

\subsection{The Patient Groups}

For this study, we re-considered the Rai clinical stages [16] of the involved CLL patients according to the recommendations of the consensus guidelines of the International Workshop on Chronic Lymphocytic Leukemia (IWCLL), which were updated in 2018 [12]. The newly diagnosed CLL patients $(n=61)$ were divided into three groups depending on the frequency of the CD38-positive cells within the $\mathrm{PB} \mathrm{CD} 19^{+} \mathrm{CD}^{+}$lymphocytes. The CD38-negative group (CD38 $8^{-}$group) included patients $(n=22)$ with a frequency of the $\mathrm{CD} 38^{+} \mathrm{CD} 19^{+} \mathrm{CD}^{+}$cells less than $6.0 \%$. In the $\mathrm{CD} 38$-moderate group $\left(\mathrm{CD} 38^{+}\right.$ group) $(n=23)$, the percentages of the $\mathrm{CD} 38^{+} \mathrm{CD} 19^{+} \mathrm{CD}^{+}$cells ranged from $6.0 \%$ to $30.0 \%$ (median: $19.8 \%)$. Finally, the CD38-positive group $\left(\mathrm{CD} 38^{++}\right.$group) included patients $(n=16)$ with more than $30 \%$ (median: $54.6 \%$; range: $33.4-79.3 \%$ ) of the $\mathrm{CD} 38^{+}$cells within the circulating $\mathrm{CD} 19^{+} \mathrm{CD}^{+}$lymphocytes. The clinical parameters of the newly diagnosed CLL patients included in the cohort groups are shown in Table 1.

Table 1. Demographic and clinical parameters of the newly diagnosed chronic lymphocytic leukemia (CLL) patients.

\begin{tabular}{|c|c|c|c|}
\hline $\begin{array}{l}\text { Demographic and } \\
\text { Clinical Parameters }\end{array}$ & $\begin{array}{c}\text { CD38- Group }^{(1)} \\
n=22\end{array}$ & $\begin{array}{c}\text { CD38 }^{+} \text {Group }^{(2)} \\
n=23\end{array}$ & $\begin{array}{c}\text { CD38 }^{++} \text {Group }^{(3)} \\
n=16\end{array}$ \\
\hline Age in years: mean (range) & $69.3(49-86)$ & $70.0(54-88)$ & $65.6(41-79)$ \\
\hline Gender: Male number (\%) & $10(45.5 \%)$ & $11(47.8 \%)$ & $11(68.8 \%)$ \\
\hline Female number $(\%)$ & $12(54.5 \%)$ & $12(52.2 \%)$ & $5(31.2 \%)$ \\
\hline $\begin{array}{l}\text { Low-risk disease } \\
\text { (Rai stage 0), } n(\%)\end{array}$ & $16(72.7 \%)$ & $7(30.4 \%)$ & $8(50.0 \%)$ \\
\hline $\begin{array}{l}\text { Intermediate-risk disease } \\
\quad \text { (Rai stages I-II), } n(\%)\end{array}$ & $6(27.3 \%)$ & $11(47.8 \%)$ & $4(25.0 \%)$ \\
\hline $\begin{array}{c}\text { High-risk disease } \\
\text { (Rai stages III-IV), } n(\%)\end{array}$ & $0(0.0 \%)$ & $5(21.7 \%)$ & $4(25.0 \%)$ \\
\hline Lymphadenopathy, $n$ (\%) & $2(9.1 \%)$ & $8(34.8 \%)$ & $5(31.3 \%)$ \\
\hline Splenomegaly, $n(\%)$ & $2(9.1 \%)$ & $7(30.4 \%)$ & $5(31.3 \%)$ \\
\hline $\begin{array}{c}\text { Leukocytosis (white blood cells), } \\
\text { 1099/L: Range } \\
\text { Median (IQR: Q1-Q3) }\end{array}$ & $\begin{array}{c}8.4-81.8 \\
18.1(12.6-42.5)\end{array}$ & $\begin{array}{c}9.3-142.7 \\
18.5(14.7-65.3)\end{array}$ & $\begin{array}{c}10.7-133.2 \\
19.3(15.0-33.3)\end{array}$ \\
\hline Lymphocytosis, $10^{9} / \mathrm{L}$ : Range & $5.4-66.4$ & 2.7-99.0 & 6.7-103.0 \\
\hline Median (IQR: Q1-Q3) & $16.6(7.8-40.8)$ & $13.5(9.4-59.2)$ & $14.1(9.5-32.9)$ \\
\hline Monocytosis, $10^{9} / \mathrm{L}$ : Range & $0.2-8.8$ & $0.4-16.1$ & $0.4-11.7$ \\
\hline Median (IQR: Q1-Q3) & $0.6(0.4-1.9)$ & $1.0(0.5-2.1)$ & $0.7(0.6-1.9)$ \\
\hline Neutrophilia, $10^{9} / \mathrm{L}$ : Range & 1.1-21.9 & 1.9-25.1 & 2.4-10.8 \\
\hline Median (IQR: Q1-Q3) & $3.4(2.9-4.4)$ & $4.4(3.1-6.4)$ & $3.7(3.2-5.2)$ \\
\hline $\begin{array}{l}\text { Red blood cell count, } 10^{12} / \mathrm{L} \text { : } \\
\text { Range } \\
\text { Median (IQR: Q1-Q3) }\end{array}$ & $\begin{array}{c}1.1-5.2 \\
4.1(3.9-4.5)\end{array}$ & $\begin{array}{c}3.0-5.2 \\
4.3(3.8-4.6)\end{array}$ & $\begin{array}{c}3.3-4.8 \\
4.2(4.1-4.5)\end{array}$ \\
\hline Hemoglobin, g/L: Range & $45.0-167.0$ & 9.5-157.0 & $11.8-162.0 * *$ \\
\hline Median (IQR: Q1-Q3) & $128.0(124.0-139.5)$ & $122.0(92.5-138.0)$ & $112.5(13.6-130.0)$ \\
\hline Platelets, $10^{9} / \mathrm{L}$ : Range & $128.0-285.0$ & $57.0-335.0$ & 110.0-261.0 \\
\hline Median (IQR: Q1-Q3) & $175.0(147.0-218.0)$ & 221.5 (153.8-241.5) & $173.5(141.8-206.0)$ \\
\hline
\end{tabular}


Table 1. Cont.

\begin{tabular}{|c|c|c|c|}
\hline $\begin{array}{l}\text { Demographic and } \\
\text { Clinical Parameters }\end{array}$ & $\begin{array}{c}\text { CD38- Group }^{(1)} \\
n=22\end{array}$ & $\begin{array}{c}\text { CD38 }^{+} \text {Group }^{(2)} \\
n=23\end{array}$ & $\begin{array}{c}\text { CD38 }^{++} \text {Group }^{(3)} \\
n=16\end{array}$ \\
\hline $\begin{array}{l}\text { CD19+ cells (among } \\
\text { lymphocytes), \%: Range } \\
\text { Median (IQR: Q1-Q3) }\end{array}$ & $\begin{array}{c}58.1-97.1 \\
83.7(76.2-91.1)\end{array}$ & $\begin{array}{c}47.0-95.9 \\
82.0(73.5-87.2)\end{array}$ & $\begin{array}{c}37.3-98.5 \\
78.6(66.5-85.7)\end{array}$ \\
\hline $\begin{array}{l}\text { CD23+ cells (among } \\
\text { lymphocytes), \%: Range } \\
\text { Median (IQR: Q1-Q3) }\end{array}$ & $\begin{array}{c}33.5-85.3 \\
71.6(59.3-78.6)\end{array}$ & $\begin{array}{c}10.8-84.6 \\
56.5(47.5-76.3)\end{array}$ & $\begin{array}{c}24.7-86.1 \\
60.5(46.9-71.1)\end{array}$ \\
\hline $\begin{array}{c}\text { CD3+ cells (among lymphocytes), } \\
\text { \%: Range } \\
\text { Median (IQR: Q1-Q3) }\end{array}$ & $\begin{array}{c}3.0-23.0 \\
14.5(7.7-19.8)\end{array}$ & $\begin{array}{c}3.0-49.0 \\
12.1(8.5-21.5)\end{array}$ & $\begin{array}{c}1.1-40.0 \\
13.1(9.0-22.1)\end{array}$ \\
\hline $\begin{array}{l}\text { CD19+CD5+ (among } \\
\text { lymphocytes), \%: Range } \\
\text { Median (IQR: Q1-Q3) }\end{array}$ & $\begin{array}{c}46.0-88.4 \\
74.1(61.8-78.6)\end{array}$ & $\begin{array}{c}32.0-93.0 * * \\
56.0(45.6-66.0)\end{array}$ & $\begin{array}{c}24.8-98.0 * * \\
54.2(39.2-70.8)\end{array}$ \\
\hline $\begin{array}{l}\text { EBV DNA > } 50 \text { copies } / 1 \text { ug of } \\
\text { PBMC DNA), } n \text { (copy number) }\end{array}$ & $0 /(0.0)$ & $2 /(441 ; 871)$ & $1 /(430)$ \\
\hline $\begin{array}{c}\text { Relative ZAP70 mRNA level in } \\
\text { PBMC: Range } \\
\text { Median (IQR: Q1-Q3) }\end{array}$ & $\begin{array}{c}0.31-8.18 \\
2.29(1.09-3.06)\end{array}$ & $\begin{array}{c}0.49-14.25 \\
2.85(1.92-5.48)\end{array}$ & $\begin{array}{c}0.07-7.79 \\
2.98(1.60-4.14)\end{array}$ \\
\hline \multicolumn{4}{|c|}{ 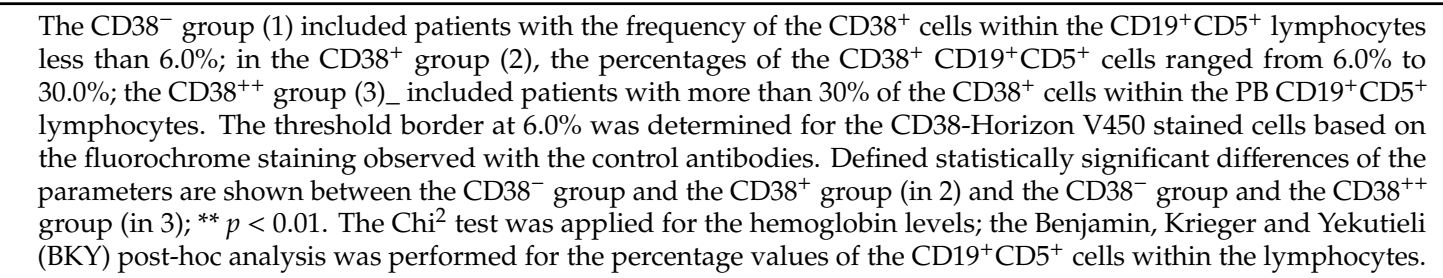 } \\
\hline
\end{tabular}

The clinical Rai staging classification showed the concordance with the proportions of the CD38-expressing $\mathrm{CD} 19^{+} \mathrm{CD}^{+}$lymphocytes (Table 1 ). In the $\mathrm{CD} 38^{-}$group, there were no patients with the high-risk disease (the Rai stages III-IV), and the majority of patients (72.7\%) had the low-risk disease (Rai stage 0 ) at the time of diagnosis. By contrast, in the CD $38^{++}$group, $25 \%$ of patients had the intermediate-risk disease (the Rai stages I-II) and $25 \%$ of patients were with the high-risk disease (the Rai stages III-IV). Noteworthy, the frequency of the Rai clinical stages differed statistically significant between the CD38-negative group and the CD38-positive groups, namely the CD38 ${ }^{+}$group and the $\mathrm{CD}_{3} 8^{++}$group, but not between two CD38-positive groups (Figure 1a). We observed the notable prevalence of male patients and lower ages in the $\mathrm{CD} 38^{++}$group. The majority of the clinical parameters did not differ significantly between the groups. However, the percentage of the $\mathrm{CD} 19^{+} \mathrm{CD} 5^{+}$ cells within the lymphocyte set differed statistically significant between the CD38-negative group and the CD38-positive groups (the $\mathrm{CD} 38^{+}$group and the $\mathrm{CD} 38^{++}$group) of the newly diagnosed patients (Figure 1c). Significant difference of the hemoglobin levels was observed between the CD38- group and the $\mathrm{CD} 38^{++}$group of patients (Table 1, Figure 1b). Evidently, these results require validation in a large CLL patient cohort.

In our study of 61 newly diagnosed CLL patients, 58 patients had fewer than 50 copies of $E B V$ DNA per $1 \mu \mathrm{g}$ of PBMC DNA (or $<30$ EBV DNA copies per $10^{5}$ PBMCs). More than 400 copies of $E B V$ DNA per $1 \mu \mathrm{g}$ were found in three patients only. Two patients from the CD38 ${ }^{+}$group had $\sim 441 \mathrm{copies} / \mu \mathrm{g}$ (with the frequency of the $\mathrm{CD} 38^{+}, \mathrm{CCR} 1^{+}$, and CCR2 ${ }^{+}$cells within the $\mathrm{CD} 19^{+} \mathrm{CD} 5^{+}$lymphocytes of $10.1 \%, 10.6 \%$, and $13.0 \%$, respectively) and $\sim 871$ copies $/ \mu g$ (with the frequency of the CD38 $8^{+}, \mathrm{CCR} 1^{+}$, and CCR2 ${ }^{+}$cells within the $\mathrm{CD} 19^{+} \mathrm{CD}^{+}$lymphocytes of $29.6 \%, 28.4 \%$, and $22.7 \%$, respectively) EBV DNA copies, respectively, and one patient from the $\mathrm{CD} 38^{++}$group had $\sim 430$ copies/ $\mu \mathrm{g}$ of the $E B V$ DNA copies (with the frequency of the $\mathrm{CD} 38^{+}, \mathrm{CCR} 1^{+}$, and $\mathrm{CCR} 2^{+}$cells within the $\mathrm{CD} 19^{+} \mathrm{CD} 5^{+}$lymphocytes of $53.0 \%, 26.8 \%$, and $26.3 \%$, respectively). 
(a) Rai clinical stage

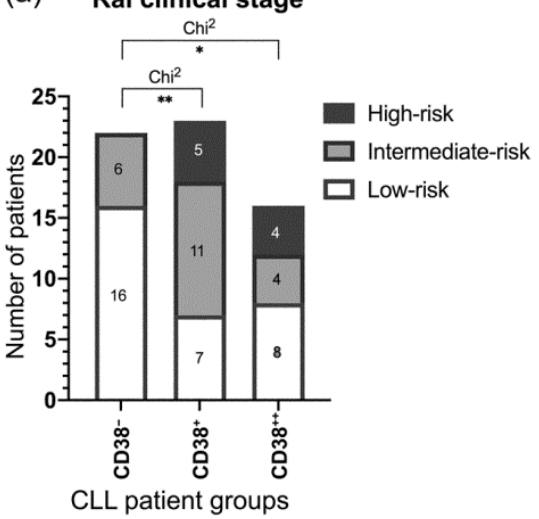

CD19+CD5+ in

(c) Lymphocytes

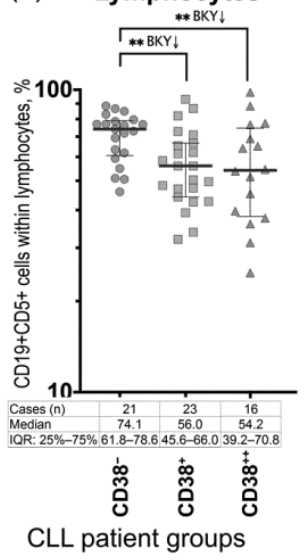

(b)

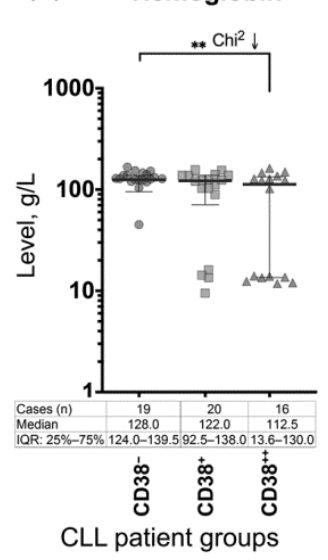

(d) T-NK/B cell ratio

(e) ZAP70/GUSB ratio

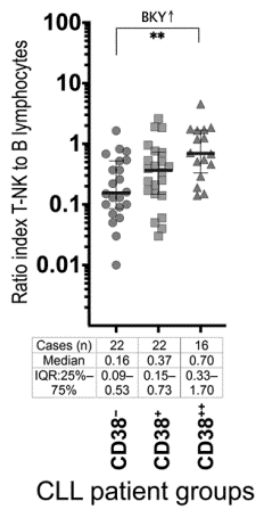

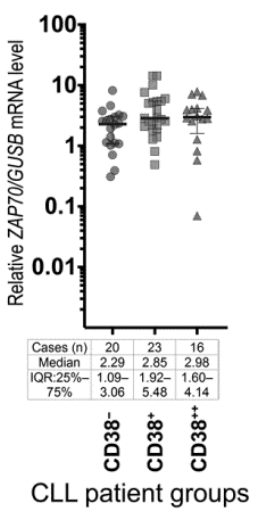

Figure 1. Statistically significant clinical parameters of the newly diagnosed CD38-negative and CD38-positive chronic lymphocytic leukemia (CLL) patients. (a) The frequency of the clinical stages by Rai classification within the $\mathrm{CD} 38^{-}$group and the CD38-positive groups, the $\mathrm{CD} 38^{+}$group and the $\mathrm{CD}_{3} 8^{++}$group. (b) The peripheral blood (PB) hemoglobin levels in the CD38-negative and CD38-positive groups of patients. (c) The percentage of the $\mathrm{CD} 19^{+} \mathrm{CD} 5^{+}$cells within the lymphocyte set in the CD38- group and the CD38-positive groups. (d) T-NK/B cell ratios, the ratios of the frequency of $\mathrm{CD} 19^{-}$lymphocytes (designated as T-NK lymphocytes) to the frequency of CD19+ $\mathrm{B}$ lymphocytes within the PBMC set of the patients were determined using flow cytrommetry. (e) The relative ZAP70 mRNA expression levels in the peripheral blood mononuclear cells (PBMC) of CLL patients was determined using real-time polymerase chain reaction (RT-PCR); the ZAP70 mRNA expression values were normalized to the housekeeping gene GUSB mRNA expression values (ZAP70/GUSB) and the levels of $Z A P 70 \mathrm{mRNA}$ expression were calculated relative to the inter-run calibrator. $\mathrm{CD}^{-} 8^{-}$, the $\mathrm{CD}^{-} 8^{-}$ group of patients with $<6.0 \%$ of the $\mathrm{CD} 38^{+}$cells within the PB CD $19^{+} \mathrm{CD} 5^{+}$lymphocytes; $\mathrm{CD} 38^{+}$, the $\mathrm{CD} 38^{+}$group of patients with $6.0-30.0 \%$ of the $\mathrm{CD} 38^{+}$cells within the $\mathrm{PB} \mathrm{CD} 19^{+} \mathrm{CD} 5^{+}$lymphocytes; $\mathrm{CD} 38^{++}$, the $\mathrm{CD} 38^{++}$group of patients with $>30.0 \%$ of the $\mathrm{CD} 38^{+}$cells within the $\mathrm{PB} \mathrm{CD} 19^{+} \mathrm{CD} 5^{+}$ lymphocytes. The median and IQR ( $25 \%$ percentile and $75 \%$ percentile) values are presented in the tables; BKY, the Benjamin, Krieger and Yekutieli test; ${ }^{* *} p<0.01$.

\subsection{Expression of CCR1 and CCR2 on Peripheral Blood Mononuclear Cells}

Expression of CCR1 and CCR2 on the cell surface of the PB lymphocytes, $\mathrm{CD} 19^{+} \mathrm{CD} 5^{+}, \mathrm{CD} 19^{+} \mathrm{CD}^{-}$, and $\mathrm{CD} 19^{-}$(designated as T-NK lymphocytes), and PB monocytes was determined in CLL patients in all groups. Nevertheless, differences in the number of the CCR1- and CCR2-positive patients and the frequency of the CCR1 $1^{+}$and $\mathrm{CCR} 2^{+} \mathrm{PB}$ lymphocytes were statistically significant between the $\mathrm{CD} 38^{-}$group and the $\mathrm{CD} 38$-positive groups, the $\mathrm{CD} 38^{+}$group and the $\mathrm{CD} 38^{++}$group (Figure 2a-c). Notably, in the $\mathrm{CD} 38^{-}$group, the percentage median values of the CCR1 $1^{+}$and $\mathrm{CCR} 2^{+}$lymphocytes, 
i.e., $\mathrm{CD} 19^{+} \mathrm{CD}^{+}, \mathrm{CD} 19^{+} \mathrm{CD}^{-}$, and T-NK lymphocytes, were below the positivity threshold border (baseline) of $10.0 \%$.

The CCR1 ${ }^{+}$and CCR2 ${ }^{+} \mathrm{CD} 19^{-}$lymphocytes (designated as T-NK lymphocytes) were also found in patients in all groups, but the percentage median values of the positive cells were located below or, in two instances, close to the positivity baseline $(10.0 \%)$, namely $11.8 \%$ of the CCR $1^{+}$T-NK lymphocytes in the $\mathrm{CD} 38^{++}$group and $11.9 \%$ of the CCR2 ${ }^{+} \mathrm{T}-\mathrm{NK}$ lymphocytes in the $\mathrm{CD} 38^{+}$group (Figure $2 \mathrm{c}$ ). In the CD $38^{++}$group, only $53.3 \%$ of patients were CCR1-positive and $50.0 \%$ of patients were CCR2-positive, with $\geq 10.0 \%$ (the threshold border) of the positive T-NK lymphocytes, respectively.

Notably, the number of patients with the CCR $1^{+}$and CCR2 ${ }^{+} \mathrm{CD} 19^{+} \mathrm{CD}^{+}$lymphocytes was essentially higher in the CD38-positive groups compared to the CD $38^{-}$group: $87.0 \%$ and $78.3 \%$, respectively, of the cases in the $\mathrm{CD} 38^{+}$group, and $75.0 \%$ and $87.5 \%$, respectively, of the cases in the $\mathrm{CD} 38^{++}$group versus $28.6 \%$ and $42.9 \%$, respectively, in the CD38 ${ }^{-}$group (Figure $2 \mathrm{a}$ ). The differences in frequency of the CCR1- and CCR2-positive $\mathrm{CD} 19^{+} \mathrm{CD}^{+}$lymphocytes were statistically significant between the $\mathrm{CD} 38^{-}$group and the $\mathrm{CD} 38$-positive groups and the percentage median values were also higher in the CD38-positive groups than in the CD $38^{-}$group: $18.4 \%$ and $15.7 \%$ in the $\mathrm{CD} 38^{+}$group, respectively, and $25.0 \%$ and $16.7 \%$ in the $\mathrm{CD}^{2} 8^{++}$group, respectively, versus $4.6 \%$ and $8.9 \%$ (below the positivity baseline of $10.0 \%$ ), respectively, in the $\mathrm{CD} 38^{-}$group.

The higher number of patients with the CCR1 $1^{+}$and CCR2 ${ }^{+} \mathrm{CD} 19^{+} \mathrm{CD} 5^{-}$lymphocytes and a higher frequency of the CCR $1^{+}$and CCR2 ${ }^{+} \mathrm{CD} 19^{+} \mathrm{CD} 5^{-}$lymphocytes were also observed in the CD38-positive groups relative to the $\mathrm{CD} 38^{-}$group (Figure $2 \mathrm{~b}$ ): $78.3 \%$ of the $\mathrm{CCR} 1^{+}$cases with the percentage median value of $19.0 \%$, and $81.8 \%$ of the CCR $2^{+}$cases with the median value of $22.0 \%$ in the $\mathrm{CD}^{+} 8^{+}$group, and $86.7 \%$ of the CCR1 $1^{+}$cases with the median value of $27.4 \%$, and $68.8 \%$ of the CCR2 ${ }^{+}$cases with the median value of $22.4 \%$ in the $\mathrm{CD} 38^{++}$group versus $23.8 \%$ of the CCR $1^{+}$cases (the median value: $6.2 \%$ ) and $40.9 \%$ of the CCR2 ${ }^{+}$cases (the median value: $8.7 \%$ ) in the CD38 $8^{-}$group. The differences between the $\mathrm{CD} 38^{-}$group and the CD38-positive groups were statistically significant (Figure $2 \mathrm{~b}$ ).

Both CCR1 and CCR2 respond to a number of the same chemokines and can duplicate a function or substitute each other $[1,2,34]$. Therefore, we estimated the frequency of the PB lymphocytes $\left(\mathrm{CD} 19^{+} \mathrm{CD}^{+}, \mathrm{CD} 9^{+} \mathrm{CD}^{-}\right.$, and T-NK) that were expressing one receptor or another (designated as $\mathrm{CCR}^{+} / \mathrm{CCR} 2^{+}$) (Figure $2 \mathrm{~d}$ ). The number of patients with the $\mathrm{CCR} 1^{+} / \mathrm{CCR} 2^{+} \mathrm{CD} 19^{+} \mathrm{CD}^{+}$lymphocytes was 1.7-fold higher in the CD38 $8^{+}$group $(87.0 \%)$ and 2.0 -fold higher in the CD38 $8^{++}$group $(100 \%)$ compared to the $\mathrm{CD} 38^{-}$group $(50.0 \%)$. The differences in the frequency median values of the $\mathrm{CCR} 1^{+} / \mathrm{CCR} 2^{+} \mathrm{CD} 19^{+} \mathrm{CD} 5^{+}$lymphocytes were statistically significant between the $\mathrm{CD} 38^{-}$group and the $\mathrm{CD} 38$-positive groups, namely the $\mathrm{CD} 38^{+}$group and the $\mathrm{CD} 38^{++}$group, and the median values were also 2.2- and 2.7-fold higher in the $\mathrm{CD} 38^{+}$group and the $\mathrm{CD} 38^{++}$group, respectively, than in the CD38- group (Figure 2d). We also determined that in the CD38-positive groups, there was a higher number of patients with the CCR $1^{+} / \mathrm{CCR} 2^{+} \mathrm{CD} 19^{+} \mathrm{CD} 5^{-}$lymphocytes; a 1.9 -fold increase was observed in the $\mathrm{CD} 38^{+}$group $\left(87.0 \%\right.$ of the positive cases) and in the $\mathrm{CD} 38^{++}$group $(87.5 \%$ of the positive cases), relative to the $\mathrm{CD} 38^{-}$group ( $45.5 \%$ of the positive cases). The frequencies of the $\mathrm{CCR} 1^{+} / \mathrm{CCR} 2^{+} \mathrm{CD} 19^{+} \mathrm{CD}^{-}$lymphocytes were 2.9 - and 3.1-fold higher in the CD38-positive groups, the $\mathrm{CD} 38^{+}$group and the $\mathrm{CD} 38^{++}$group, respectively, than in the $\mathrm{CD} 38^{-}$group and these differences were also significant $(p<0.01)$ (Figure $2 \mathrm{~d}$ ). 

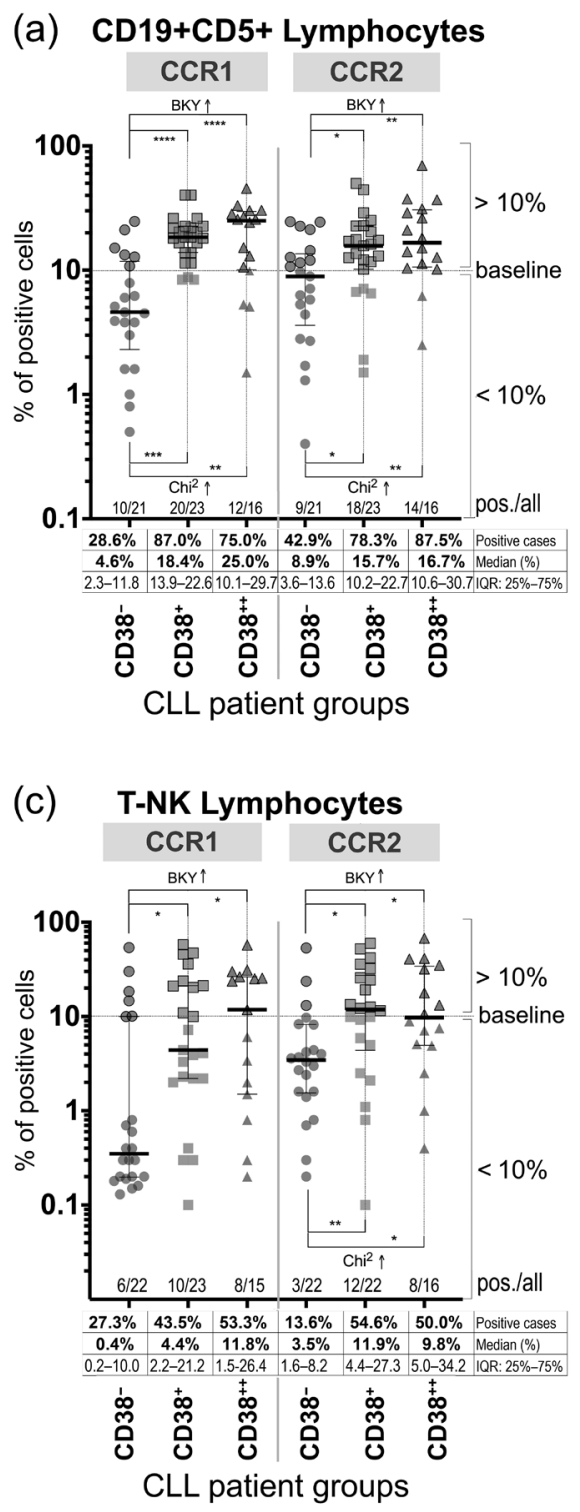

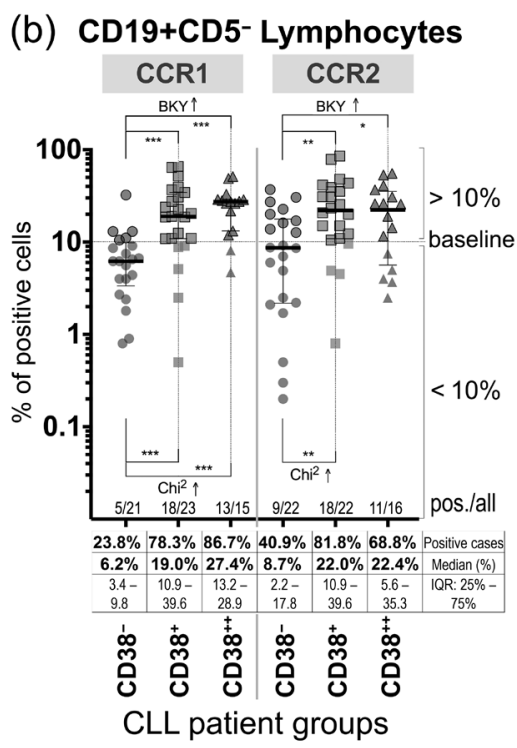

(d) CD19+CD5+ CD19+CD5CCR1/CCR2 CCR1/CCR2

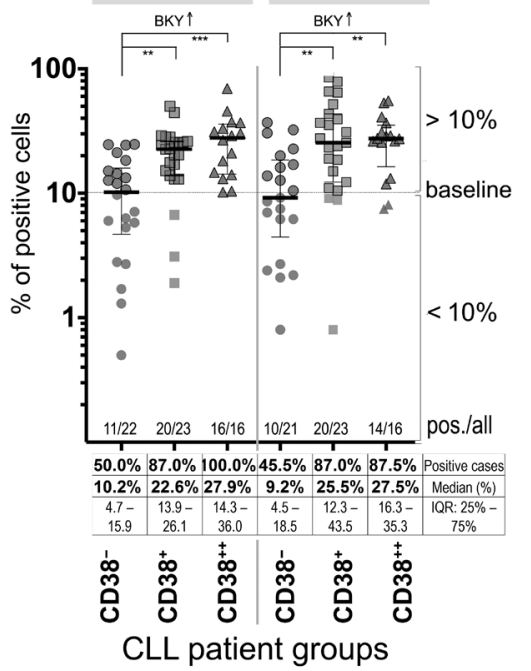

Figure 2. Frequency of the CCR1- and CCR2-expressing peripheral blood lymphocytes in the newly diagnosed CD38-negative and CD38-positive CLL patients. Frequency of the CCR1 ${ }^{+}$and CCR2 ${ }^{+}$ cells within the $\mathrm{CD} 19^{+} \mathrm{CD}^{+}$lymphocytes $(\mathbf{a}), \mathrm{CD} 19^{+} \mathrm{CD}^{-}$lymphocytes (b), and $\mathrm{CD} 19^{-}$lymphocytes (designated as T-NK lymphocytes) (c) are shown. (d) Frequency of the CCR1 ${ }^{+}$or CCR2 ${ }^{+}$(designated as $\left.\mathrm{CCR} 1^{+} / \mathrm{CCR}^{+}\right) \mathrm{CD} 19^{+} \mathrm{CD}^{+}$lymphocytes and $\mathrm{CD} 19^{+} \mathrm{CD}^{-}$lymphocytes. $\mathrm{CD} 38^{-}$, the $\mathrm{CD} 38^{-}$ group of patients with $<6.0 \%$ of the $\mathrm{CD} 38^{+}$cells within the $\mathrm{PB} \mathrm{CD} 19^{+} \mathrm{CD} 5^{+}$lymphocytes; $\mathrm{CD} 38^{+}$, the $\mathrm{CD} 38^{+}$group of patients with $6.0-30.0 \%$ of the $\mathrm{CD} 38^{+}$cells within the $\mathrm{PB} \mathrm{CD} 19^{+} \mathrm{CD} 5^{+}$lymphocytes; $\mathrm{CD} 38^{++}$, the $\mathrm{CD} 38^{++}$group of patients with $>30.0 \%$ of the $\mathrm{CD} 38^{+}$cells within the $\mathrm{PB} \mathrm{CD} 19^{+} \mathrm{CD}^{+}$ lymphocytes. For CCR1 and CCR2, $\geq 10.0 \%$ of the fluorochrome-stained cells within the selected gate were considered to be positive cells; the positivity threshold border (baseline) of $10.0 \%$ was defined in our study for the CD191/CD192-Alexa 647 stained cells, based on the fluorochrome staining recorded for the control Ig-isotype antibodies and Annexin V-PerCP-Cy5.5. The percentages of positive cells from two experiments (with two tubes per experiment) were averaged. Data were collected when at least 100 cells displayed the immunophenotype. On plots, the median and IQR $(25 \%$ percentile and $75 \%$ percentile) values are shown; $\mathrm{Chi}^{2}$, the Chi-square test; $\mathrm{BKY}$, the method of Benjamin, Krieger and Yekutieli; ${ }^{*} p<0.05,{ }^{* *} p<0.01,{ }^{* * *} p<0.001,{ }^{* * * *} p<0.0001$. 
The overall Spearman's rank correlation analysis of all the CLL patients in the study revealed positive correlations between expression of $\mathrm{CD} 38$ on the $\mathrm{PBCD} 19^{+} \mathrm{CD}^{+}$lymphocytes and the presence of CCR1, CCR2, and CCR1/CCR2 on these lymphocytes. The Spearman's rank correlation coefficients were defined as follows: $\mathrm{r}_{\mathrm{S}}=0.50(p<0.0001), \mathrm{r}_{\mathrm{S}}=0.38(p=0.002)$, and $\mathrm{r}_{\mathrm{S}}=0.51(p<0.0001)$, respectively (Figure 3). It should be noted that only a part of the $\mathrm{CD} 38^{+} \mathrm{CD} 19^{+} \mathrm{CD} 5^{+}$cells expressed CCR1 or CCR2. Interestingly, the blood hemoglobin levels correlated negatively with the frequency of the $\mathrm{CD} 38^{+}$and $\mathrm{CCR}^{+} / \mathrm{CCR} 2^{+} \mathrm{CD} 19^{+} \mathrm{CD}^{+}$PB lymphocytes $\left(\mathrm{r}_{\mathrm{s}}=-0.36, p=0.01\right.$ and $\mathrm{r}_{\mathrm{s}}=-0.45, p=0.0007$, respectively) (Figure S1). The other clinical parameters used in the study (Table 1) did not correlate with the CD38- or CCR1-/CCR2-positivity of the $\mathrm{CD} 19^{+} \mathrm{CD}^{+} \mathrm{PB}$ lymphocytes. Although, the correlations were observed between the lymphocyte phenotype markers, CD19, CD23, and CD3, and the blood cell counts of the white blood cells (WBC), red blood cells (RBC), neutrophils, lymphocytes, and monocytes (Figure S1).

Expression of CCR1 and CCR2 on the PB monocytes was detected in all the study patients. The percentage median values of the CCR1- and CCR2-expressing monocytes exceeded $50.0 \%$ in all three groups, with no statistically significant differences between the groups. The values were as follows: $50.3 \%$ (IQR: $35.2-61.0 \%$ ) and 66.5\% (IQR: 40.5-75.9\%), respectively, in the CD38 ${ }^{-}$group; $51.3 \%$ (IQR: $35.3-63.8 \%$ ) and $72.1 \%$ (IQR: 53.7-83.3\%), respectively, in the CD38 ${ }^{+}$group; and $65.0 \%$ (IQR: $41.7-82.3 \%$ ) and $69.0 \%$ (IQR: $47.5-84.1 \%$ ), respectively, in the CD $38^{++}$group.

\subsection{ZAP70 Relative mRNA Expression in the Peripheral Blood Mononuclear Cells}

We determined the relative normalized-to-GUSB ZAP70 mRNA expression levels in the PBMC fractions of the patients. Proportions of the CD19- lymphocytes (designated as T-NK) and CD19 ${ }^{+}$ lymphocytes (B) within the PBMC set were assessed, using $\mathrm{mFC}$, and the ratios of the T-NK to B lymphocytes (T-NK/B) were calculated. In the $\mathrm{CD} 38^{-}$group, the relative ZAP70-expression level median value was 2.29 (IQR: 1.09-3.06) (Figure 1e). This median value was taken as the baseline for comparison of the relative ZAP70 mRNA expression levels in the CD38-positive patients. In our study, the $\geq 3$-fold elevated ZAP70 expression levels, compared to the median value of 2.29 (baseline) in the $\mathrm{CD} 38^{-}$group, were only found in four patients $(17.4 \%)$ in the $\mathrm{CD} 38^{+}$group, namely 7.61 (with T-NK/B = 0.14), 10.03 (with T-NK/B = 0.43), 14.22 (with $\mathrm{T}-\mathrm{NK} / \mathrm{B}=0.06$ ), and 14.25 (with $\mathrm{T}-\mathrm{NK} / \mathrm{B}=0.24)$; and in three patients $(18.8 \%)$ in the $\mathrm{CD} 38^{++}$group, namely 6.81 (with $\mathrm{T}-\mathrm{NK} / \mathrm{B}=1.25$ ), 7.09 (with $\mathrm{T}-\mathrm{NK} / \mathrm{B}=0.71$ ), and 7.79 (with $\mathrm{T}-\mathrm{NK} / \mathrm{B}=0.55$ ). The median values in the $\mathrm{CD} 38^{+}$group and $\mathrm{CD} 38^{++}$group were as follows: 2.85 (range: 0.49-14.25) and 2.98 (range: 0.07-7.79), respectively, for the relative ZAP70 expression levels, and 0.37 (range: 0.03-2.59) and 0.70 (range: 0.14-4.52), respectively, for the T-NK/B ratios (Figure 1e,d). The PBMC relative ZAP70 mRNA expression levels had no statistically significant differences between three groups of the study CLL patients. However, the PBMC ZAP70 mRNA expression levels correlated weak-to-low positively with the presence of $\mathrm{CD} 38$ on the $\mathrm{CD} 19^{+} \mathrm{CD}^{+}$lymphocytes $\left(\mathrm{r}_{\mathrm{s}}=0.29 ; p=0.03\right)$ (Figure 3$)$. Nevertheless, no correlations were detected between the relative ZAP70 expression levels and the T-NK/B ratios, as well as the frequency of CCR1, or CCR2 on the $\mathrm{CD} 19^{+} \mathrm{CD}^{+}$lymphocytes (Figure 3). Notably, while the T-NK/B ratios correlated with the frequency of $\mathrm{CD} 38$ on the $\mathrm{CD} 19^{+} \mathrm{CD}^{+}$lymphocytes, the clinical parameter "proportions of $\mathrm{CD} 19^{+} \mathrm{CD}^{+}$cells within lymphocytes" did not (Figure 3). 


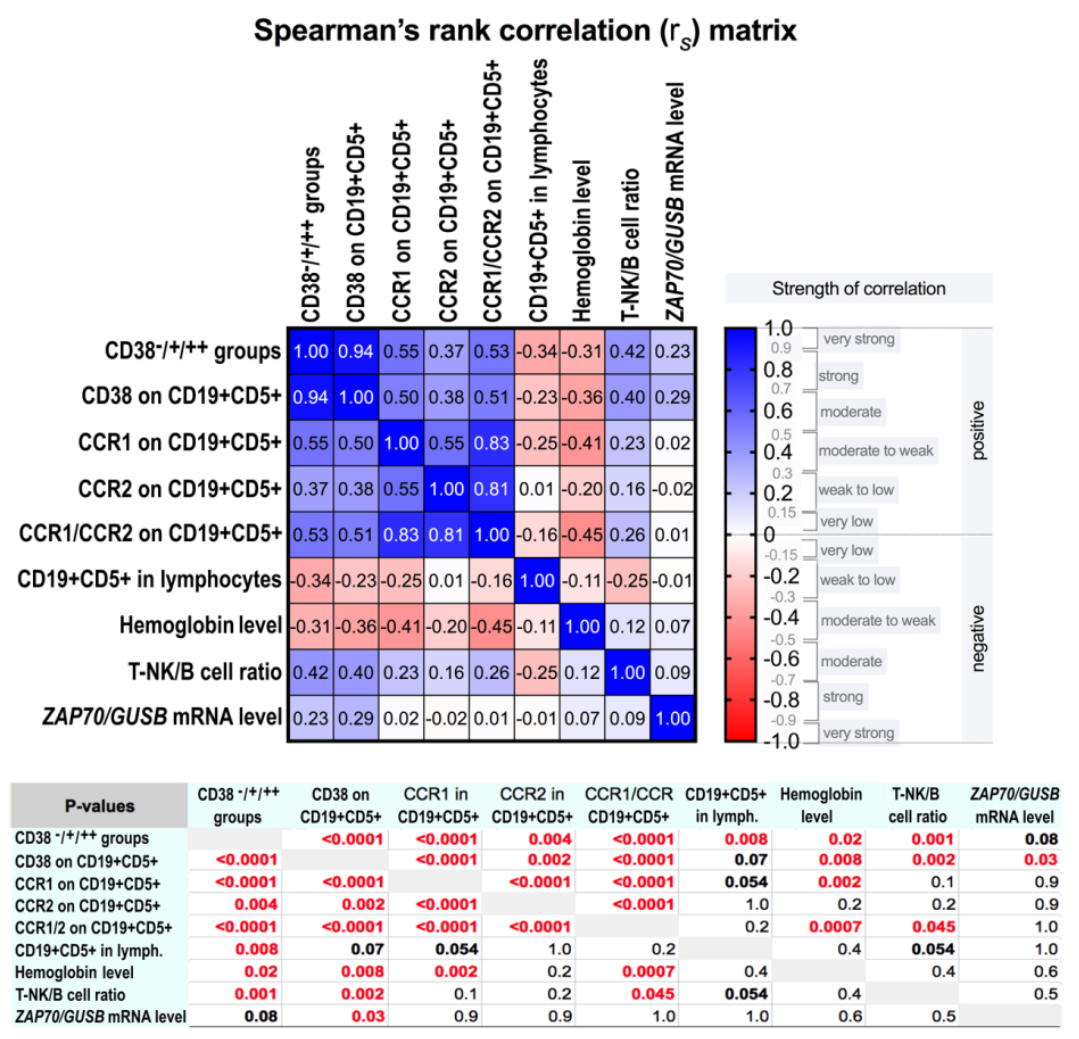

Figure 3. Spearman's rank correlation analysis of the frequencies of the CD38-, CCR1-, and CCR2-expressing peripheral blood (PB) $\mathrm{CD} 19^{+} \mathrm{CD}^{+}$lymphocytes in the newly diagnosed CLL patients. The Spearman's rank correlation analysis matrix is shown. CD38 on $\mathrm{CD} 19^{+} \mathrm{CD} 5^{+}$, the frequency of the CD38-expressing cells within the PB CD $19^{+} \mathrm{CD} 5^{+}$lymphocytes; CCR1 on $\mathrm{CD} 19^{+} \mathrm{CD} 5^{+}$and $\mathrm{CCR} 2$ on $\mathrm{CD} 19^{+} \mathrm{CD}^{+}$, the frequencies of the corresponding receptor-expressing cells within the $\mathrm{PB}$ $\mathrm{CD} 19^{+} \mathrm{CD}^{+}$lymphocytes; CCR1/CCR2 on $\mathrm{CD} 19^{+} \mathrm{CD} 5^{+}$, the frequency of the CCR1- or CCR2-expressing cells within the PB CD19 ${ }^{+} \mathrm{CD} 5^{+}$lymphocytes; ZAP70/GUSB, the relative normalized-to-GUSB ZAP70 mRNA expression levels in the PBMC fractions; T-NK/B cell ratio, the ratios of the frequency of $\mathrm{CD} 19^{-}$lymphocytes (designated as T-NK lymphocytes) to the frequency of CD19 ${ }^{+} \mathrm{B}$ lymphocytes. In the table, the corresponding P-values are presented. Note, the p-values between the ZAP70 mRNA expression levels and the frequency of CCR1, CCR2, and CCR1/CCR2 on the CD19+ CD $5{ }^{+}$lymphocytes are exceeding the significance cut-off value of 0.05 .

\section{Discussion}

Within our cohort of newly diagnosed CLL patients $(n=61)$, which included 39 patients with the CD38-expressing leukemic cells, we determined a positive correlation between expression of CD38 (the negative predictor of CLL progression) and expression of the chemokine receptors CCR1 and CCR2 on the PB CD $19^{+} \mathrm{CD}^{+}$lymphocytes $\left(\mathrm{r}_{\mathrm{s}}=0.50\right.$ and $\mathrm{r}_{\mathrm{s}}=0.38$, respectively). Noteworthy, in the all patients with $\geq 30 \%$ of the $\mathrm{CD} 38^{+} \mathrm{CD} 19^{+} \mathrm{CD} 5^{+}$lymphocytes (the $\mathrm{CD} 38^{++}$group, $n=16$ ), we determined CCR 1 or CCR2 or both on the $\mathrm{CD} 19^{+} \mathrm{CD} 5^{+}$cells (with the median cumulative frequency of $27.9 \%$ ). In $87.0 \%$ of patients in the $\mathrm{CD} 38^{+}$group (with $\geq 6 \%$ and $<30 \%$ of the $\mathrm{CD} 38^{+} \mathrm{CD} 19^{+} \mathrm{CD} 5^{+}$lymphocytes, $n=23$ ), these receptors were also detected on the $\mathrm{CD} 19^{+} \mathrm{CD} 5^{+}$cells (with the median cumulative frequency of $22.6 \%$ ). While in the CD38 $8^{-}$group $(n=22)$, CCR 1 or CCR2 were found in $50.0 \%$ of the patients, the frequency median value of $10.2 \%$ was near the positivity cut-of border of $10.0 \%$. Interestingly, the CCR1 and CCR2 expression on the $\mathrm{PB} \mathrm{CD19}{ }^{+} \mathrm{CD}^{-}$and $\mathrm{CD}^{-} 9^{-}$(designated as T-NK) lymphocytes was also enhanced in the CD38-positive patients, and the differences between the CD38-negative group and the CD38-positive groups were significant. Extrinsic signals of the microenvironment can be involved into interplay between PB cell subsets. In the case of the cell-surface receptors, as chemokine 
receptors, the lack of the ligands (antagonists or agonists) allow a receptor to escape internalization into the cell cytoplasm for the further processing and recycling [2]. The relevance of the CCR1 and CCR2 expression in distinct PB cell and lymphocyte subsets to the CLL pathogenesis is required to be investigated.

CCR1 and CCR2 in monocytes, macrophages, and T cells have been studied in many diseases (reviewed in $[1,3])$. However, the function of CCR1 or CCR2 in B lymphocytes is currently unknown. Earlier, we reported the up-regulation of CCR1 and CCR2 in PB B cells activated in vitro [10] and in circulating B and T lymphocytes in patients with rheumatoid arthritis [35]. CCR1 and CCR2 comprise protein sequence similarity [2] and respond to a number of the same chemokines, which are abundantly secreted in the lymphoid organs (reviewed in $[1,3,34,36]$ ). Both CCR1 and CCR2 respond to the chemokines CCL7, CCL8, and CCL16, which are expressed at high levels in the tissues of bone marrow (CCL7), spleen (CCL8), tonsil (CCL8), and liver (CCL16). Besides, the CCR1 ligands (endogenous agonists) are abundantly secreted in bone marrow (CCL3), lymph nodes (CCL4, CCL14), spleen (CCL3, CCL14), and liver (CCL14, CCL15). The CCR2-ligand CCL2 is found in the liver tissues [34,36]. In our earlier studies, we demonstrated the enhanced migration of the CCR2-expressing B cells toward the CCR2 dominant ligand chemokine CCL2 (MCP1) [10,37]. Chemotactic migration of the CCR1/CCR2-expressing CLL cells into the secondary organs, such as lymph nodes, spleen, and/or liver, contributes, apparently, to the aggressive pathogenesis of the disease.

In two recent reports, a mechanism of action for homing chemokine receptors, CCR7, CXCR3, CXCR4, and CCR2, in CLL cells via p66Shc, an adaptor protein, was suggested [38,39]. In B lymphocytes, p66Shc acts as a negative regulator of the BCR-activated signaling and the chemotactic responses, but promotes lymphocyte apoptosis. Since the p66Shc expression was impaired in CLL cells compared to the healthy subjects, involvement of this adaptor protein in CLL pathogenesis was implied. Noteworthy that expression of the CCR7, CXCR3, and CCR2 on CLL cells negatively correlated with the p66Shc expression [38]. The authors described the putative mechanisms whereby p66Shc deficiency in CLL cells induces expression of the homing chemokine receptors and down-regulates expression of the egress receptor S1PR1 (reviewed in [39]).

Higher EBV DNA-copy number (>1000 copies/ $\mu$ g of DNA) in PBMCs of patients at CLL diagnosis was significantly associated with other established unfavorable prognostic factors, such as the IGHV mutational status, CD38-positive or ZAP-70-positive phenotype of CLL cells, and the presence of the del(11q22.3) cytogenetic abnormality [28,29]. On the contrary, the multivariate analysis showed that the poor prognosis of the high EBV DNA load was reflecting more prominent tumor aggressiveness, regardless of clinical stage of the CLL disease, or age. Furthermore, no significant relationship between EBV DNA-copy number and unmutated IGHV was observed. Thus, the multivariate analysis demonstrated that the EBV DNA load at diagnosis is an independent predictor of overall survival in patients with CLL [30]. A quantitative test for EBV DNA load was suggested to be integrated in the assessment of patients with newly diagnosed CLL to evaluate their outcome [28-30]. However, in our study of 61 newly diagnosed CLL patients, more than 50 copies of EBV DNA per $1 \mu \mathrm{g}$ of PBMC DNA were determined in 3 patients only, reflecting, possibly, the geographic and/or seasonal impact on EBV activation and transient immunosuppression.

Next-generation sequencing studies have disclosed intra-tumor heterogeneity in CLL. Some somatic mutations (as in MYD88) and chromosomal abnormalities (as del(13q) and trisomy 12) are mostly found in the all leukemic cells indicating that these alterations occurred early in leukemia genesis. Other mutations (as in SF3B1 and NOTCH1) and chromosomal abnormalities (as del(17p) are often found in a fraction of the CLL cells, thus representing sub-clonal diversity, which occurs later in the development of CLL. Sub-clonal distribution of mutations is associated with more aggressive form of the disease (reviewed in [11,12]). Nevertheless, the previous studies reported that the IGHV mutational status has prognostic significance independent of cytogenetic findings in CLL [40,41]. Interphase fluorescence in situ hybridization (FISH) and TP53 mutation analyses are not essential to diagnose CLL but help predict the treatment response and should guide therapeutic decisions [12]. 
Until now, the somatic mutation status of the IGHV gene is the most valuable prognostic in CLL [11]. However, identification of the expressed IGHV segments and the IGHV mutation status, the FISH and mutation analyses are more expensive and complicated than flow cytometry tests for routine clinical practice and are still unavailable to many patients, particularly in Eastern European countries. In Latvia, the government healthcare system financially supports the FISH and mutation analyses only for CLL patients with the age $\leq 50$ years old and patients who did not respond to the first-line therapy. Currently, two indicators of the CLL high-risk progression, ZAP-70 and CD38 in leukemic cells, are being used in routine clinical FC tests. However, ZAP-70 showed worse concordance with the IGHV mutation status than did CD38 [26,27].

In the rather small cohort of the untreated CLL patients in our study $(n=61)$, we did not observe any correlation between the ZAP70 mRNA expression levels in the PBMCs and the CCR1- or CCR2-positivity of the PB CD19 ${ }^{+} \mathrm{CD}^{+}$lymphocytes. However, the PBMC ZAP70 mRNA expression levels correlated positively moderate-to-week $\left(r_{\mathrm{s}}=0.29\right)$ with the frequency of the $\mathrm{CD} 38^{+} \mathrm{PB} \mathrm{CD} 19^{+} \mathrm{CD} 5^{+}$lymphocytes, according to the Spearman's rank correlation statistical analysis (Figure 3). In an early study of 107 CLL patients, in $93 \%$ of patients the ZAP70 expression level was 5.54-fold higher in patients with unmutated IGHV than in patients with mutated IGHV, and thus, ZAP-70 was suggested to be a prognostic indicator in CLL [42]. However, in another study of 127 CLL patients, ZAP-70 protein expression was not predictive of survival in patients with Binet's stage B and C [43].

CD38 expression on the PB leukemic cells has been reported as a CLL negative prognostic factor, predicting shorter overall survival, in numerous publications, but with various cut-off levels. In the first report in 1999 and the following studies, CD38 expression predicted survival rates when $\geq 30 \%$ of leukemic cells were determined as CD38-positive $[25,28,44]$. In other studies, the cut-off levels of $20 \%[45,46]$ or even $7 \%[47,48]$ of the CD38-expresing CLL cells were applied. In our study, we divided the CD38-positive CLL patients into two groups, the $\mathrm{CD} 38^{+}$group and the $\mathrm{CD} 38^{++}$group, with the cut-off levels of $6.0-30.0 \%$ and $>30.0 \%$, respectively, of the CD38-positive cells within the circulating $\mathrm{CD} 19^{+} \mathrm{CD}^{+}$lymphocytes. Noteworthy that the Rai clinical stages and the frequency of the $\mathrm{CCR} 1^{+} / \mathrm{CCR} 2^{+}$lymphocytes differed statistically significantly between the CD38-negative group and the $\mathrm{CD} 38^{+}$group, and between the $\mathrm{CD} 38$-negative group and the $\mathrm{CD} 38^{++}$group, but not between two CD38-positive groups. Taking into account the correlation analyses data, our results indicate the CD38 expression on $>6 \%$ of the $\mathrm{PB} \mathrm{CD} 19^{+} \mathrm{CD}^{+}$lymphocytes as a risk factor in CLL patients at diagnosis. Further efforts are necessary to establish the common cut-off level of the CD38-expresing cells for the risk evaluation in CLL.

The strong association of the CD38 and CD49d (the alpha chain of the alpha4beta1 integrin heterodimer) expression on CLL cells has been first reported by Zucchetto and coauthors [49] and then confirmed in several studies. CD49d was shown to be an independent prognostic marker in patients with CLL (reviewed in [50]). The combined CD38/CD49d phenotype was the strongest FC-based predictor of overall survival and the treatment-free survival in large cohorts of patients with CLL $[50,51]$, supporting the previous suggestion of the scoring system based on the expression of several cell-surface antigens for correct risk stratification in CLL [52].

New predictor markers, i.e., reliable prognostic indicators of the high-risk progression in CLL patients at disease presentation, which can be introduced into routine diagnostic procedures (such as the immunophenotypical identification using flow cytometry), are still needed. We demonstrated an association of the CCR1/CCR2 expression on the circulating $\mathrm{CD} 19^{+} \mathrm{CD} 5^{+}$lymphocytes with the CD38-positivity of these lymphocytes. Our results suggest that flow cytometric detection of CCR1 and CCR2 on the PB leukemic cells, along with CD38, could serve as an additional indicator predicting the high risk of disease progression in CLL patients at diagnosis.

We are reporting that in newly diagnosed CLL patients with the expression of the high-risk progression marker CD38 on leukemic cells, the chemokine receptors CCR1 and CCR2 were up-regulated on the $\mathrm{PB} \mathrm{CD} 19^{+} \mathrm{CD}^{+}$lymphocytes, indicating their increased migration capability toward chemokine-ligands secreting organs. Functions of the chemokine receptors CCR1 and CCR2 
in B lymphocytes, in healthy or pathological conditions, are largely unknown. Disclosure of the role of CCR1 and CCR2 in the pathogenesis of CLL could suggest these receptors and their signaling pathways as targets for the development of anti-progression therapeutics in CLL.

\section{Conclusions}

In our study of 61 newly diagnosed CLL patients, which included 39 patients with CD38-positive leukemic cells, we demonstrated the presence of the chemokine receptors CCR1 and CCR2 on the circulating $\mathrm{CD} 19^{+} \mathrm{CD}^{+}$and $\mathrm{CD} 19^{+} \mathrm{CD}^{-}$lymphocytes in the $\mathrm{CD} 38$-positive patients. Furthermore, the frequency of the CCR1- and/or CCR2-expressing CD19+CD5 $5^{+}$lymphocytes positively correlated with the frequency of the CD38-expressing $\mathrm{CD} 19^{+} \mathrm{CD}^{+}$lymphocytes. Detection of CCR1 and CCR2 on the $\mathrm{PB} \mathrm{CD} 19^{+} \mathrm{CD}^{+}$lymphocytes could be suggested in routine diagnostic FC tests, in addition to CD38, for accurate prognosis of the high-risk progression in CLL patients at diagnosis. However, further association studies with an extended patient cohort are necessary to verify whether the presence of CCR1 and/or CCR2 on circulating leukemic cells is a reliable prognostic indicator in CLL.

Supplementary Materials: The following are available online at http://www.mdpi.com/2077-0383/9/7/2312/s1: Figure S1: Spearman's rank correlation analysis of the clinical parameters and the frequencies of the CD38-, CCR1-, and CCR2-expressing peripheral blood (PB) $\mathrm{CD} 19^{+} \mathrm{CD}^{+}$lymphocytes in the newly diagnosed CLL patients.

Author Contributions: Conceptualization, I.K., A.R., and S.L.; formal analysis, M.S., I.V., L.H., I.S., S.K., J.P., and S.S.; methodology and investigation, I.K., A.R., L.H., I.S., I.V., and S.K.; resources, M.M. and S.L.; data curation, A.R. and I.K.; statistical analyses and visualization, S.S.; writing-original draft preparation, I.K.; writing-review and editing, S.L., A.R., M.M., S.S., S.K., and I.K.; project administration, I.K., S.L., and S.K.; funding acquisition, I.K. All authors have read and agreed to the published version of the manuscript.

Funding: This research was funded by the Latvian Council of Science projects No. 651/2014 and No. lzp-2018/1-0156.

Conflicts of Interest: The authors declare no conflict of interest. The funders had no role in the design of the study; in the collection, analyses, or interpretation of data; in the writing of the manuscript; or in the decision to publish the results.

\section{References}

1. White, G.E.; Iqbal, A.J.; Greaves, D.R. CC chemokine receptors and chronic inflammation-therapeutic opportunities and pharmacological challenges. Pharmacol. Rev. 2013, 65, 47-89. [CrossRef] [PubMed]

2. Stone, M.; Hayward, J.A.; Huang, C.E.; Huma, Z.; Sanchez, J. Mechanisms of Regulation of the Chemokine-Receptor Network. Int. J. Mol. Sci. 2017, 18, 342. [CrossRef]

3. Zabel, B.A.; Rott, A.; Butcher, E.C. Leukocyte chemoattractant receptors in human disease pathogenesis. Annu. Rev. Pathol. 2015, 10, 51-81. [CrossRef] [PubMed]

4. Frade, J.M.; Mellado, M.; del Real, G.; Gutierrez-Ramos, J.C.; Lind, P.; Martinez, A.C. Characterization of the CCR2 chemokine receptor: Functional CCR2 receptor expression in B cells. J. Immunol. 1997, 159, 5576-5584. Available online: https://www.jimmunol.org/content/159/11/5576 (accessed on 3 February 2020). [PubMed]

5. Corcione, A.; Tortolina, G.; Bonecchi, R.; Battilana, N.; Taborelli, G.; Malavasi, F.; Sozzani, S.; Ottonello, L.; Dallegri, F.; Pistoia, V. Chemotaxis of human tonsil B lymphocytes to CC chemokine receptor (CCR) 1, CCR2 and CCR4 ligands is restricted to non-germinal center cells. Int. Immunol. 2002, 14, 883-892. [CrossRef] [PubMed]

6. Johansson, C.; Ahlstedt, I.; Furubacka, S.; Johnsson, E.; Agace, W.W.; Quiding-Järbrink, M. Differential expression of chemokine receptors on human IgA+ and IgG+ B cells. Clin. Exp. Immunol. 2005, 141, 279-287. [CrossRef]

7. Fung, E.L.; Esposito, J.A.; Todd, L.S. Wicker Multiplexed immunophenotyping of human antigen-presenting cells in whole blood by polychromatic flow cytometry. Nat. Protoc. 2010, 5, 357-370. [CrossRef]

8. Trentin, L.; Cabrelle, A.; Facco, M.; Carollo, D.; Miorin, M.; Tosoni, A.; Pizzo, P.; Binotto, G.; Nicolardi, L.; Zambello, R.; et al. Homeostatic chemokines drive migration of malignant B cells in patients with non-Hodgkin lymphomas. Blood 2004, 104, 502-508. [CrossRef]

9. Anderson, M.W.; Zhao, S.; Ai, W.Z.; Tibshirani, R.; Levy, R.; Lossos, I.S.; Natkunam, Y. C-C chemokine receptor 1 expression in human hematolymphoid neoplasia. Am. J. Clin. Pathol. 2010, 133, 473-483. [CrossRef] 
10. Kholodnyuk, I.; Rudevica, Z.; Leonciks, A.; Ehlin-Henriksson, B.; Kashuba, E. Expression of the chemokine receptors CCR1 and CCR2B is up-regulated in peripheral blood B cells upon EBV infection and in established lymphoblastoid cell lines. Virology 2017, 512, 1-7. [CrossRef]

11. Kipps, T.J.; Stevenson, F.K.; Wu, C.J.; Croce, C.M.; Packham, G.; Wierda, W.G.; O’Brien, S.; Gribben, J.; Rai, K. Chronic lymphocytic leukaemia. Nat. Rev. Dis. Primers 2017, 3, 16096. [CrossRef]

12. Hallek, M.; Cheson, B.D.; Catovsky, D.; Caligaris-Cappio, F.; Dighiero, G.; Döhner, H.; Hillmen, P.; Keating, M.; Montserrat, E.; Chiorazzi, N.; et al. IwCLL guidelines for diagnosis, indications for treatment, response assessment, and supportive management of CLL. Blood 2018, 131, 2745-2760. [CrossRef] [PubMed]

13. Herth, I.; Dietrich, S.; Benner, A.; Hegenbart, U.; Rieger, M.; Stadtherr, P.; Bondong, A.; Tran, T.H.; Weide, R.; Hensel, M.; et al. The impact of allogeneic stem cell transplantation on the natural course of poor-risk chronic lymphocytic leukemia as defined by the EBMT consensus criteria: A retrospective donor versus no donor comparison. Ann. Oncol. 2014, 25, 200-206. [CrossRef] [PubMed]

14. Nakhla, P.S.; Butera, J.N.; Treaba, D.O.; Castillo, J.J.; Quesenberry, P.J. Spontaneous regression of chronic lymphocytic leukemia to a monoclonal B-lymphocytosis or to a normal phenotype. Leuk. Lymphoma 2013, 54, 1647-1651. [CrossRef] [PubMed]

15. Kern, W.; Bacher, U.; Schnittger, S.; Dicker, F.; Alpermann, T.; Haferlach, T.; Haferlach, C. Flow cytometric identification of 76 patients with biclonal disease among 5523 patients with chronic lymphocytic leukaemia (B-CLL) and its genetic characterization. Br. J. Haematol. 2014, 164, 565-569. [CrossRef]

16. Rai, K.R.; Sawitsky, A.; Cronkite, E.P.; Chanana, A.D.; Levy, R.N.; Pasternack, B.S. Clinical staging of chronic lymphocytic leukemia. Blood 1975, 46, 219-234. [CrossRef]

17. Binet, J.L.; Leporrier, M.; Dighiero, G.; Charron, D.; Vaugier, G.; Beral, H.M.; Natali, J.C.; Raphael, M.; Nizet, B.; Follezou, J.Y. A clinical staging system for chronic lymphocytic leukemia: Prognostic significance. Cancer 1977, 40, 855-864. [CrossRef]

18. Shanafelt, T.D.; Geyer, S.M.; Kay, N.E. Prognosis at diagnosis: Integrating molecular biologic insights into clinical practice for patients with CLL. Blood 2004, 103, 1202-1210. [CrossRef]

19. Binet, J.L.; Caligaris-Cappio, F.; Catovsky, D.; Cheson, B.; Davis, T.; Dighiero, G.; Dohner, H.; Hallek, M.; Hillmen, P.; Keating, M.; et al. Perspectives on the use of new diagnostic tools in the treatment of chronic lymphocytic leukemia. Blood 2006, 107, 859-861. [CrossRef]

20. Damle, R.N.; Wasil, T.; Fais, F.; Ghiotto, F.; Valetto, A.; Allen, S.L.; Buchbinder, A.; Budman, D.; Dittmar, K.; Kolitz, J.; et al. Ig V gene mutation status and CD38 expression as novel prognostic indicators in chronic lymphocytic leukemia. Blood 1999, 94, 1840-1847. [CrossRef] [PubMed]

21. Hamblin, T.J.; Davis, Z.; Gardiner, A.; Oscier, D.G.; Stevenson, F.K. Unmutated Ig V(H) genes are associated with a more aggressive form of chronic lymphocytic leukemia. Blood 1999, 94, 1848-1854. [CrossRef] [PubMed]

22. Hamblin, T.J.; Orchard, J.A.; Gardiner, A.; Oscier, D.G.; Davis, Z.; Stevenson, F.K. Immunoglobulin V genes and CD38 expression in CLL. Blood 2000, 95, 2455-2457. [CrossRef] [PubMed]

23. Del Poeta, G.; Maurillo, L.; Venditti, A.; Buccisano, F.; Epiceno, A.M.; Capelli, G.; Tamburini, A.; Suppo, G.; Battaglia, A.; Del Principe, M.I.; et al. Clinical significance of CD38 expression in chronic lymphocytic leukemia. Blood 2001, 98, 2633-2639. [CrossRef] [PubMed]

24. Malavasi, F.; Deaglio, S.; Damle, R.; Cutrona, G.; Ferrarini, M.; Chiorazzi, N. CD38 and chronic lymphocytic leukemia: A decade later. Blood 2011, 118, 3470-3478. [CrossRef]

25. Damle, R.; Temburni, S.; Calissano, C.; Yancopoulos, S.; Banapour, T.; Sison, C.; Allen, S.L.; Rai, K.R.; Chiorazzi, N. CD38 expression labels an activated subset within chronic lymphocytic leukemia clones enriched in proliferating B cells. Blood 2007, 110, 3352-3359. [CrossRef]

26. Rassenti, L.; Huynh, L.; Toy, T.L.; Chen, L.; Keating, M.J.; Gribben, J.G.; Neuberg, D.S.; Flinn, I.W.; Rai, K.R.; Byrd, J.C.; et al. ZAP-70 compared with immunoglobulin heavy-chain gene mutation status as a predictor of disease progression in chronic lymphocytic leukemia. N. Engl. J. Med. 2004, 351, 893-901. [CrossRef]

27. Chen, Y.H.; Peterson, L.C.; Dittman, D.; Evens, A.; Rosen, S.; Khoong, A.; Shankey, T.V.; Forman, M.; Gupta, R.; Goolsby, C.L. Comparative analysis of flow cytometric techniques in assessment of ZAP-70 expression in relation to IgVH mutational status in chronic lymphocytic leukemia. Am. J. Clin. Pathol. 2007, 127, 182-191. [CrossRef] 
28. Liang, J.H.; Gao, R.; Xia, Y.; Gale, R.P.; Chen, R.Z.; Yang, Y.Q.; Wang, L.; Qu, X.Y.; Qiu, H.R.; Cao, L.; et al. Prognostic impact of Epstein-Barr virus (EBV)-DNA copy number at diagnosis in chronic lymphocytic leukemia. Oncotarget 2016, 7, 2135-2142. [CrossRef]

29. Grywalska, E.; Roliński, J.; Pasiarski, M.; Korona-Glowniak, I.; Maj, M.; Surdacka, A.; Grafka, A.; Stelmach-Gołdyś, A.; Zgurski, M.; Góźdź, S.; et al. High Viral Loads of Epstein-Barr Virus DNA in Peripheral Blood of Patients with Chronic Lymphocytic Leukemia Associated with Unfavorable Prognosis. PLoS ONE 2015, 10, e0140178. [CrossRef]

30. Visco, C.; Falisi, E.; Young, K.H.; Pascarella, M.; Perbellini, O.; Carli, G.; Novella, E.; Rossi, D.; Giaretta, I.; Cavallini, C.; et al. Epstein-Barr virus DNA load in chronic lymphocytic leukemia is an independent predictor of clinical course and survival. Oncotarget 2015, 30, 18653-18663. [CrossRef]

31. Pozarowski, P.; Grabarek, J.; Darzynkiewicz, Z. Current Protocols in Cell Biology; Bonifacino, J.S., Ed.; Wiley: New York, NY, USA, 2004; Chapter 18; pp. 18.8.1-18.8.33. [CrossRef]

32. Gladkikh, A.A.; Potashnikova, D.M.; Tatarskiy, V., Jr.; Yastrebova, M.; Khamidullina, A.; Barteneva, N.; Vorobjev, I. Comparison of the mRNA expression profile of B-cell receptor components in normal CD5-high B-lymphocytes and chronic lymphocytic leukemia: A key role of ZAP70. Cancer Med. 2017, 6, 2984-2997. [CrossRef] [PubMed]

33. Valceckiene, V.; Kontenyte, R.; Jakubauskas, A.; Griskevicius, L. Selection of reference genes for quantitative polymerase chain reaction studies in purified B cells from B cell chronic lymphocytic leukaemia patients. Br. J. Haematol. 2010, 151, 232-238. [CrossRef] [PubMed]

34. Bachelerie, F.; Ben-Baruch, A.; Charo, I.F.; Combadiere, C.; Farber, J.M.; Förster, R.; Graham, G.J.; Hills, R.; Horuk, R.; Locati, M.; et al. Chemokine receptors (version 2019.5) in the IUPHAR/BPS Guide to Pharmacology Database. IUPHAR/BPS Guide Pharmacol. CITE 2019, 5, 1-37. [CrossRef]

35. Kholodnyuk, I.; Kadisa, A.; Svirskis, S.; Gravelsina, S.; Studers, P.; Spaka, I.; Sultanova, A.; Lejniece, S.; Lejnieks, A.; Murovska, M. Proportion of the CD19-Positive and CD19-Negative Lymphocytes and Monocytes within the Peripheral Blood Mononuclear Cell Set is Characteristic for Rheumatoid Arthritis. Medicina (Kaunas Lith.) 2019, 55, 630. [CrossRef] [PubMed]

36. Uhlén, M.; Fagerberg, L.; Hallström, B.M.; Lindskog, C.; Oksvold, P.; Mardinoglu, A.; Sivertsson, Å.; Kampf, C.; Sjöstedt, E.; Asplund, A.; et al. Tissue-based map of the human proteome. Science 2015, 347, 6220. Human Protein Atlas available from http://www.proteinatlas.org (accessed on 18 February 2020). [CrossRef]

37. Kozireva, S.; Rudevica, Z.; Baryshev, M.; Leonciks, A.; Kashuba, E.; Kholodnyuk, I. Upregulation of the Chemokine Receptor CCR2B in Epstein-Barr Virus-Positive Burkitt Lymphoma Cell Lines with the Latency III Program. Viruses 2018, 10, 239. [CrossRef]

38. Patrussi, L.; Capitani, N.; Ulivieri, C.; Manganaro, N.; Granai, M.; Cattaneo, F.; Kabanova, A.; Mundo, L.; Gobessi, S.; Frezzato, F.; et al. P66Shc deficiency in the E $\mu$-TCL1 mouse model of chronic lymphocytic leukemia enhances leukemogenesis by altering the chemokine receptor landscape. Haematologica 2019, 104, 2040-2052. [CrossRef]

39. Patrussi, L.; Capitani, N.; Baldari, C.T. P66Shc: A Pleiotropic Regulator of B Cell Trafficking and a Gatekeeper in Chronic Lymphocytic Leukemia. Cancers 2020, 12, 1006. [CrossRef]

40. Rassenti, L.Z.; Jain, S.; Keating, M.J.; Wierda, W.G.; Grever, M.R.; Byrd, J.C.; Kay, N.E.; Brown, J.R.; Gribben, J.G.; Neuberg, D.S.; et al. Relative value of ZAP-70, CD38, and immunoglobulin mutation status in predicting aggressive disease in chronic lymphocytic leukemia. Blood 2008, 112, 1923-1930. [CrossRef]

41. Lin, K.I.; Tam, C.S.; Keating, M.J.; Wierda, W.G.; O’Brien, S.; Lerner, S.; Coombes, K.R.; Schlette, E.; Ferrajoli, A.; Barron, L.L.; et al. Relevance of the immunoglobulin VH somatic mutation status in patients with chronic lymphocytic leukemia treated with fludarabine, cyclophosphamide, and rituximab (FCR) or related chemoimmunotherapy regimens. Blood 2009, 113, 3168-3171. [CrossRef]

42. Wiestner, A.; Rosenwald, A.; Barry, T.S.; Wright, G.; Davis, R.E.; Henrickson, S.E.; Zhao, H.; Ibbotson, R.E.; Orchard, J.A.; Davis, Z.; et al. ZAP-70 expression identifies a chronic lymphocytic leukemia subtype with unmutated immunoglobulin genes, inferior clinical outcome, and distinct gene expression profile. Blood 2003, 101, 4944-4951. [CrossRef]

43. Oppezzo, P.; Vasconcelos, Y.; Settegrana, C.; Jeannel, D.; Vuillier, F.; Legarff-Tavernier, M.; Kimura, E.Y.; Bechet, S.; Dumas, G.; Brissard, M.; et al. The LPL/ADAM29 expression ratio is a novel prognosis indicator in chronic lymphocytic leukemia. Blood 2005, 106, 650-657. [CrossRef] 
44. Hamblin, T.J.; Orchard, J.A.; Ibbotson, R.E.; Davis, Z.; Thomas, P.W.; Stevenson, F.K.; Oscier, D.G. CD38 expression and immunoglobulin variable region mutations are independent prognostic variables in chronic lymphocytic leukemia, but CD38 expression may vary during the course of the disease. Blood 2002, 99, 1023-1029. [CrossRef] [PubMed]

45. Ibrahim, S.; Keating, M.; Do, K.A.; O’Brien, S.; Huh, Y.O.; Jilani, I.; Lerner, S.; Kantarjian, H.M.; Albitar, M. CD38 expression as an important prognostic factor in B-cell chronic lymphocytic leukemia. Blood 2001, 98, 181-186. [CrossRef] [PubMed]

46. Durig, J.; Naschar, M.; Schmucker, U.; Renzing-Kohler, K.; Holter, T.; Huttmann, A.; Duhrsen, U. CD38 expression is an important prognostic marker in chronic lymphocytic leukaemia. Leuk. Off. J. Leuk. Soc. Am. Leuk. Res. Fund UK 2002, 16, 30-35.

47. Krober, A.; Seiler, T.; Benner, A.; Bullinger, L.; Bruckle, E.; Lichter, P.; Dohner, H.; Stilgenbauer, S. V(H) mutation status, CD38 expression level, genomic aberrations, and survival in chronic lymphocytic leukemia. Blood 2002, 100, 1410-1416. [CrossRef] [PubMed]

48. Thornton, P.D.; Fernandez, C.; Giustolisi, G.M.; Morilla, R.; Atkinson, S.; A’Hern, R.P.; Matutes, E.; Catovsky, D. CD38 expression as a prognostic indicator in chronic lymphocytic leukaemia. Hematol. J. Off. J. Eur. Haematol. Assoc. EHA 2004, 5, 145-151. [CrossRef] [PubMed]

49. Zucchetto, A.; Bomben, R.; Dal Bo, M.; Bulian, P.; Benedetti, D.; Nanni, P.; Del Poeta, G.; Degan, M.; Gattei, V. CD49d in B-cell chronic lymphocytic leukemia: Correlated expression with CD38 and prognostic relevance. Leuk. Off. J. Leuk. Soc. Am. Leuk. Res. Fund UK 2006, 20, 523-525. [CrossRef]

50. Brachtl, G.; Hofbauer, J.P.; Greil, R.; Hartmann, T.N. The pathogenic relevance of the prognostic markers CD38 and CD49d in chronic lymphocytic leukemia. Ann. Hematol. 2014, 93, 361-374. [CrossRef]

51. Brachtl, G.; Sahakyan, K.; Denk, U.; Girbl, T.; Alinger, B.; Hofbauer, S.W.; Neureiter, D.; Hofbauer, J.P.; Egle, A.; Greil, R.; et al. Differential bone marrow homing capacity of VLA-4 and CD38 high expressing chronic lymphocytic leukemia cells. PLoS ONE 2011, 6, e23758. [CrossRef]

52. Zucchetto, A.; Bomben, R.; Dal Bo, M.; Sonego, P.; Nanni, P.; Rupolo, M.; Bulian, P.; Dal Maso, L.; Del Poeta, G.; Del Principe, M.I.; et al. A scoring system based on the expression of six surface molecules allows the identification of three prognostic risk groups in B-cell chronic lymphocytic leukemia. J. Cell. Physiol. 2006, 207, 354-363. [CrossRef] [PubMed] 